\title{
What motivational processes underpin student engagement with employability? A critical review
}

\author{
Andrew James Clements
}

There are concerns that students fail to engage with employability soon enough in their studies, and do not seek the best available support. This chapter explores the role that motivation plays in students' career management behaviours, notably career exploration, decision-making, and job search. The literature highlights the crucial role played by selfefficacy, i.e. belief in one's ability to perform a task, which is informed by personal experience and feedback. Time spent on career exploration (i.e. reflecting on one's own qualities and exploring opportunities) is associated with greater confidence in making career decisions. Job search behaviours, such as effort, is associated with better career outcomes. However, there is a gap in the literature regarding how earlier exploration and decision activities inform the job search. This chapter identifies opportunities for addressing this gap, and the potential value of exploring student job search strategies. Yet while attention to motivation may inform how we work with individual students, it remains necessary to consider environmental conditions in the labour market.

\section{Introduction}

Across the globe, participation in Higher Education (HE) is expanding for a number of reasons. Amongst these reasons are competitions for desired career outcomes, with nonattendance of HE incurring opportunity costs (Marginson, 2016). HEl are positioned as having responsibility to the wider economy (Hunter, 2013), e.g. via providing "work-ready" graduates (Tomlinson, 2012). In Britain, HEls are expected to justify high tuition fees through enhanced graduate employability (Tholen, 2014). Employability has variously been described as the ability to gain and maintain desired forms of employment (Rothwell \& Arnold, 2007) and a collection of achievements and understandings that promote future career success (Knight \& Yorke, 2004). More recently, Marilyn Clarke has proposed an integrative model of employability, in which perceived employability is informed by human capital, e.g. skills, social capital such as networks, individual behaviours such as career management skills, and individual attributes such as adaptability (Clarke, 2017).

Importantly, Clarke's model also acknowledges the role of labour market factors, i.e. supply and demand, on both perceived employability and actual career outcomes.

In modern labour markets, individuals are responsible for managing their own career progress and outcomes (Smith, 2010) and to be adaptable (Clarke, 2013). There have been calls for HEI to improve graduate employability, as UK government (Browne, 2010) and some portions of British industry $(\mathrm{CBI}, 2015)$ have claimed that graduates are not prepared for the world of work - although other reports have claimed that employers are generally satisfied with the quality of graduates (UK Commission for Employment and Skills, 2015). Employers report large numbers of "hard-to-fill" vacancies (CIPD, 2018), but there are signs 
of an "oversupply" of graduates (Humburg, de Grip, \& van der Velden, 2017) which is seen as resulting from mass participation in $\mathrm{HE}$ that has not been matched by increased demand for highly skilled workers (Verhaest \& Van Der Velden, 2013). This has consequences for graduates, in that there is increased competition for a finite supply of desired occupations (Helyer \& Lee, 2014). Brown and Hesketh (2004) characterise this as "positional conflict", in which graduates are now required to find means beyond the degree to make themselves distinctive to employers. Logically, while it is possible to help individual students become more employable, employability interventions are unlikely to enhance the career outcomes of graduates as a whole (Greenbank, 2017) as the number of graduate positions remains finite. My focus in this chapter therefore is necessarily on how career outcomes might be improved for individuals, although structural issues (e.g. inequality) must be considered. As noted previously, individuals have largely been given the task of managing their own careers. Inevitably people vary in how well they perform this task, for a variety of reasons. In this chapter I discuss the role that motivation plays in the pursuit of career goals.

Some scholars have expressed concern that students do not engage with employability early enough during their time in HE (Tansley, Jome, Haase, \& Martens, 2007). Early in their studies, students may be less likely to place value on work experience compared to in their final year of study (Tymon, 2013). There is evidence too that students fail to seek advice from careers services, in part because students prefer to speak to people they know and believe to know students as individuals (Greenbank, 2011). Greenbank (2011) reported that as a consequence, students preferred to speak with lecturers and family rather than careers service, even though the preferred source may lack career-specific knowledge needed by the enquiring student. For example, the parents of first-generation HE students are less likely to have labour market knowledge relevant to their children's goals (Tate et al., 2015). There are a variety of reasons that students may put off engaging with employability, including a preference for focusing on immediate concerns (e.g. assignments), preferences for career decisions based on intuition rather than research, and a tendency to passively rely on the provision of information (Greenbank, 2017). However, some students clearly engage better than others with the development of employability, despite competing demands. In order to discuss why this may be, I explore motivation theory, given that motivation reflects the direction, intensity and duration of action (Locke \& Latham, 2004).

\section{Social cognitive career theory}

Social cognitive career theory (SCCT) was formulated to account for the processes by which people form career interests, make academic and career choices, and pursue career goals (Lent, Brown, \& Hackett, 1994). A key concept in SCCT is self-efficacy, a construct representing an individual's perception of their capability (Bandura \& Cervone, 1983). In SCCT it is expected that career interests are influenced by self-efficacy, i.e. one's perceived ability in a career field, perceived outcomes (e.g. rewards) and perceived barriers (Brown \& Lent, 1996). For example, a given graduate may intend a career in management. They believe that they are capable of managing others, find the work interesting, and the pay appealing - yet whether they apply for a job in management may also be influenced by their perception that they are able to gain the job. Proposed influences on self-efficacy include previous performance, direct and indirect learning, and others' persuasion of the individual (Brown, Lent, Telander, \& Tramayne, 2011; Lent \& Brown, 1996). The hypothetical graduate seeking management work may have a sense of their own ability that is informed by their experience of a work placement, feedback from supervisors and tutors, and advice from their HEl's careers service. More recently, Lent and colleagues proposed an SCCT model of 
career self-management (CSM) which is intended to explain developmental processes in careers (Ireland \& Lent, 2018; Lent \& Brown, 2013; Lent, Ezeofor, Morrison, Penn, \& Ireland, 2016). The CSM is intended to extend SCCT, which focuses on career interests and choices - career content - by focusing on career processes such as career planning, career exploration and decision making (Lent \& Brown, 2013). CSM draws upon Savickas' concept of career adaptability, which relates to individuals' ability to adapt to changing circumstances (Savickas, 1997). The CSM distinguishes between developmental tasks, such as career decision-making and seeking employment, and coping skills that enable the individual to manage transitions such as school-to-work or job loss (Lent \& Brown, 2013). The model draws upon the earlier work by Super (1975) in distinguishing between a series of life stages, each of which are associated with particular adaptive tasks (Lent \& Brown, 2013):

- Growth, an early stage in which the emphasis is upon skill development

- Exploration, in which skills are further developed, but additional tasks include career exploration and career decision-making

- Establishment, which includes the tasks of obtaining work and adjustment to work environments

- Maintenance, which includes the task of career self-renewal, but may also lead to recycling of earlier stages (e.g. due to voluntary or involuntary departure from a job)

- Disengagement/reengagement, which can include adjustment to changing responsibilities, or adjustment from work to leisure (i.e. retirement)

In this chapter I focus on the stages of exploration and establishment. In line with the CSM, it is important to recognise that these stages may apply not only to young HE students, but also to mature students who have decided to attend HE as part of a strategy for making career changes, i.e. recycling exploration and establishment as part of the maintenance stage.

As in SCCT, the CSM proposed that learning experiences influence self-efficacy and outcome expectations, which in turn inform career goals. Contextual factors such as the presence of support and barriers are expected to influence goals, the actions implemented to pursue goals, and goal outcomes, e.g. by contributing to self-efficacy. As predicted, selfefficacy and outcome expectations have been found to influence career exploration goals (Lent et al., 2016). Learning experiences associated with success, operationalised as mastery experiences, have also been found to associate with self-efficacy (Bandura, 1977; Ireland \& Lent, 2018; Warner et al., 2018). A meta-analytic review demonstrated that cognitive ability and conscientiousness - a personality trait reflecting discipline and persistence - also influence self-efficacy (Brown et al., 2011). While SCCT and CSM identify a key role for self-efficacy, these models do not address the characteristics of career goals. For this reason, I now discuss goal setting theory.

\section{Goal setting theory}

Goal setting theory proposes that goal characteristics influence the level of effort and persistence individuals devote to their goals, and thus shapes the likelihood of success (Latham \& Locke, 2007; Locke \& Latham, 2004, 2013). Specifically, goal setting theory states that people perform better when they have "high goals," i.e. goals that are specific, achievable, and challenging (Locke \& Latham, 1990). A challenging target requires new behaviours, encouraging the formation of strategy, while the specific nature of the high goal enables an individual to monitor goal progress (Locke \& Latham, 2013). As in SCCT and CSM, self-efficacy is an important feature of the goal-setting process. Individuals with higher 
self-efficacy set themselves more challenging goals (Bandura \& Locke, 2003; Donovan, 2009) and persist longer when striving for these goals (Locke \& Latham, 2002). Feedback is an important part of the goal-striving process, as it enables individuals to see how much progress has been made, and how much is yet needed (Bandura \& Cervone, 1983). Individuals with higher levels of self-efficacy combined with goal commitment are more likely to recover from failure during goal attainment, while individuals higher in self-efficacy who succeed respond by setting new challenging goals (Bandura \& Locke, 2003).

\section{Career goal pursuit}

The creation of discrepancy is a crucial feature of goal-setting theory (Bandura \& Locke, 2003). In other words, it is thought that people are motivated to achieve, and that this therefore leads them to setting challenging goals. After all, if one merely wished to experience no discrepancy between current and desired states, it would be simpler not to set goals at all! On the other hand, discrepancies between what we want to achieve and what we have actually achieved can also create distress. Creed, Wamelink, and Hu (2015) reported that discrepancies between career goals and current states was associated with distress, although they noted that this relationship was weakened by engagement in career exploration and planning. While Creed et al (2015) conducted their survey on young people in general rather than those specifically enrolled in HE, Creed, Hood, \& Hu (2017) conducted a survey specifically on 564 young people in their first year of HE. They reported that students with proactive orientations experienced less career goal-performance discrepancy, and therefore had less career-related distress and more employability confidence, while those higher in interpersonal rejection sensitivity experienced greater career-goal discrepancy and thus higher distress and lower confidence. Through moderated mediation models, Creed et al (2017) demonstrated that goal commitment - which they treated as a measure of goal importance - buffered the impact of rejection sensitivity, and strengthened the impact of proactive orientations. In other words, when students were more committed to their career goals, those who were proactive experienced even less discrepancy, and those who were worried about disappointing others experienced less discrepancy than they otherwise would. In another study examining aspects of self-regulation in the career goal pursuit, Hu, Hood, and Creed (2017) explored the impact of negative career feedback in a sample of $184 \mathrm{HE}$ students. As might be expected, negative career feedback was associated with a greater inclination amongst students to abandon their career goals. However, this effect was weakened for those who had a higher career-related growth mindset (i.e. who see struggle as a normal part of career pursuit) and strengthened for those with a higher career-related destiny mindset (i.e. who see adversity as a sign that the career path is not "meant to be"). In a study exploring engagement with employability amongst a sample of 432 UK undergraduates, mastery approach - a tendency towards seeking challenges in order to personally develop - was associated in greater engagement with three out of four proactive career behaviours: career consultation, network building, and skill development - but not career planning (Clements \& Kamau, 2017). They reported that career goal commitment was positively associated with all four proactive career behaviours. Goal commitment is a key concept in goal setting theory (Hollenbeck, Williams, \& Klein, 1989). A meta-analytic review has demonstrated that goal commitment moderates the relationship between goal difficulty and performance, with goal commitment becoming more important at higher levels of difficulty (Klein, Wesson, Hollenbeck, \& Alge, 1999). Clements and Kamau (2017) therefore predicted that goal commitment would moderate the relationship between mastery approach, used as a proxy for the setting of challenging goals, and proactive career behaviours. Instead, they found that goal commitment acted as a full 
mediator between mastery approach and career planning, and as a partial mediator between mastery approach and the other three proactive career behaviours (career consultation, network building, and skill development). Taken together, key attributes for students to engage with employability would appear to include self-efficacy, commitment to career goals, proactive approaches and a tendency towards seeking challenge. However, drawing on the CSM, I will now explore specific stages of career goal pursuit for students.

\section{Career exploration}

Career exploration is an important activity within the exploration stage of the CSM (Lent \& Brown, 2013). Career exploration can include both self-exploration to identify relevant personal qualities or environmental exploration to identify career opportunities and barriers (Guan et al., 2017), and may take place across the life-span as a developmental process (Cheung \& Arnold, 2010). This developmental task is expected to have benefits for the ability to make career decisions, including reduced indecision or decision-related anxiety (Lent et al., 2016). In other words, career exploration should result in more confidence for students as they come to realise what their own preferences are, what options are available that align with those preferences. To the extent that career exploration identifies potential career barriers, we might expect career exploration to inform adaptation of career strategies.

Betz and Voyten (1997) conducted a study of career decision-making self-efficacy, career indecision, and career exploration in a sample of 350 students. As might be expected, career decision-making self-efficacy was negatively related to career indecision. Interestingly, they reported that career indecision was related to intentions to engage in career exploration for women, but not for men. More recently a three-wave longitudinal test of the CSM in 420 students found that exploratory intentions were positively predicted by outcome expectancies and career decision-making self-efficacy, and these intentions alongside self-efficacy in turn predicted exploratory behaviours (Lent et al., 2018). In contrast to the study by Betz and Voyten (1997), Lent et al. (2018) did not find that career indecision predicted exploration intentions. Instead, decisional anxiety was consistently negatively predicted by self-efficacy, while career decidedness was positively predicted at T2 by exploratory actions at T1, and at T3 by self-efficacy and social support measured at T2. Given the longitudinal design of the study by Lent et al (2018), we may have greater confidence in the findings, which enabled testing of reverse and reciprocal relationships. For example, the study was able to show that T2 self-efficacy was influenced by T1 decidedness - positively - and by T1 decisional anxiety - negatively. Lent and colleagues interpreted this as support for the existence of a feedback loop, with prior experiences informing selfefficacy, and thus shaping future behaviour.

Social support is a contextual factor expected to influence career exploration via enhanced self-efficacy (Lent et al., 2016). While some correlational studies have found a relationship between social support and students' career exploration (e.g. Lent et al., 2016; Zhang \& Huang, 2018), longitudinal studies have failed to support this (Cheung \& Arnold, 2010; Lent et al., 2018). Combined with the findings of Lent et al. (2018), we may perhaps expect support to influence confidence in making the right choice, rather than encouraging students to explore what choices are available. However, an important consideration may be the use that students make of support. Help-seeking behaviours receives more attention in the context of career decisions. 


\section{Career decision making}

It has been previously suggested that many students struggle to make career decisions (Tokar, Withrow, Hall, \& Moradi, 2003) and thus universities are seen as playing a role in providing students opportunities to improve in this career task (Esters \& Retallick, 2013). One of the challenges is that people vary in their tendency towards decisiveness; Jaensch, Hirschi, and Freund (2015) reported two three-wave longitudinal surveys that demonstrated a strong stable component of career indecision, which was associated with lower core selfevaluations (i.e. a generally negative view of self) and perceived career barriers. However, it should be noted that Jaensch et al did not use a full-panel design, with only career indecision measured across all three time points. Individual differences in self-awareness may play an important role in decision-making; in a study of 189 Chinese students, both goal commitment and occupational commitment were reported to mediate a relationship between emotional intelligence and career decision-making self-efficacy (Jiang, 2016). This was thought to reflect the role of self-awareness in helping students to form goals in which they are interested, leading to greater commitment.

Work-based or work-integrated learning is expected to have benefits for students' skill development (Jackson, 2015). Esters and Retallick (2013) reported that students taking part in a placement increased in career decision self-efficacy and vocational identity. A similar effect was reported by Jackson and Wilton (2016) who compared career management competencies in those participating in a placement with those who did not - although this effect was only found once the impact of current employment was controlled.

Support has also been examined as a potential influence on career decision-making. Garcia, Restubog, Bordia, Bordia, and Roxas (2015) reported that parental support and teacher support was positively associated with career decision-making self-efficacy, and that the latter was positively associated with career optimism. While this was a longitudinal study, only career optimism and demographic variables were measured at T2, which limits the rigour of the analysis. De Lange, Taris, Kompier, Houtman, and Bongers (2003) recommend the use of complete panel designs, in which the full range of measures are used at each occasion of data collection, in order to permit the identification of reverse or reciprocal causations. As well as the provision of support, support-seeking has attracted attention in career research. In a study of 1176 Israeli students, perceptions of difficulty in making career decisions was associated with greater procrastination, slower speed in making decisions, more effort in decision making, and less interest in an ideal occupation (Vertsberger \& Gati, 2015). Similarly, those who were more inclined to seek help from others were those who procrastinated, made slower decisions, with greater effort, and were inclined to consult others. As has been reported by other research (e.g. Greenbank, 2011), Vertsberger and Gati found that their participants were most likely to approach friends and family for advice, despite identifying expertise as the most important consideration in seeking help. In a longitudinal study, differences in career indecision coping style was associated with career decision difficulties and decision status (Lipshits-Braziler, Gati, \& Tatar, 2015). Specifically, non-productive coping (e.g. helplessness and isolation) was associated with greater decision difficulties; those higher in this coping were more likely to remain undecided in their career choices. Support-seeking was also higher in those who remained undecided, while productive coping (e.g. problem-solving and information-seeking) was unrelated to career difficulty or the final career decision status (i.e. decided versus undecided). 


\section{Job search}

The job search process marks a key stage in the transition from HE to work, following career decisions, but also incorporating further decisions (e.g. identification of targets and strategies). Graduates may begin with high expectations, but these are often lowered as a result of repeated rejections (McKeown \& Lindorff, 2011). Job search self-efficacy, i.e. confidence in one's ability to effectively seek work, is an important predictor of job search behaviour in students and graduates (Lim, Lent, \& Penn, 2016; Liu \& Wang, 2014), likely via the mediator of job search intentions (Lim et al., 2016). Job search self-efficacy has been predicted by conscientiousness and social support (Lim et al., 2016), career adaptability (Guan et al., 2013), and perceived job search progress (Liu \& Wang, 2014). Guan et al. (2013) reported that job search self-efficacy is associated with subsequent employment status; we may expect that this is because job search self-efficacy predicts job search behaviour, which is also associated with the number of job offers received (Liu \& Wang, 2014). However, evidence from a longitudinal study suggests that higher job search selfefficacy is associated with increased job search effort in those students motivated to avoid failure but lower effort in those motivated by success (Sun, Song, \& Lim, 2013). Thus job search self-efficacy may not be a universal panacea for motivational interventions. Given that there is far more evidence in favour of the beneficial impact of self-efficacy, it may be helpful for replication studies to take place. Da Motta Veiga and Gabriel (2016) reported a study of the dynamics of job search in business students over the course of five weeks. They found that autonomous (i.e. intrinsic) motivation for job search declined during the search period before plateauing at the mid-point, while controlled motivation (i.e. a sense of necessity) remained stable. While autonomous motivation was positively associated with strategising about job search and thereby influenced job search effort, controlled motivation was initially negatively associated with strategising and thereby effort, but became positively associated with strategizing later in the job search process.

Although there has been research exploring student and graduate engagement with the job search process, there seems to be a lack of research on the broad strategies that they use. Previous research in the broader job search literature has distinguished between focused, exploratory, and haphazard job search strategies (Bonaccio, Gauvin, \& Reeve, 2014; Crossley \& Highhouse, 2005). A focused job search is one in which the individual only seeks work in which they are interested and for which they are qualified (Crossley \& Highhouse, 2005) and choices are planful and driven by criterion rather than emotions (Bonaccio et al., 2014). This search strategy is associated positively with job offers (Koen, Klehe, Vianen, Zikic, \& Nauta, 2010), reemployment among the unemployed (Battisti, Gilardi, Guglielmetti, \& Siletti, 2016) and job satisfaction in obtained employment (Crossley \& Highhouse, 2005). Those higher in perceived employability are more likely to report using a focused job search strategy (Battisti et al., 2016), which suggests that outcome expectancies may prompt beneficial strategies. By contrast, haphazard job search is characterised by passive information gathering (e.g. relying on others to supply information), the setting of illdefined goals, a tendency to react to external events and changing tactics without rationale (Crossley \& Highhouse, 2005). In this approach, decisions are much more likely to be based in emotion (Bonaccio et al., 2014). Those adopting this approach are less likely to experience job satisfaction, because they may not clearly realise what jobs would suit them, and because they may accept the first job offer to be made (Crossley \& Highhouse, 2005). The exploratory job search strategy is one in which individuals are open to a number of job options, and is characterised by information search from a number of sources, including friends and colleagues (Crossley \& Highhouse, 2005). This search strategy is positively associated with the receipt of job offers, although a longitudinal study suggested that an 
exploratory approach was negatively associated with subsequent reemployment quality (Koen et al., 2010).

\section{Implications and future directions}

Considerable attention has been directed toward student engagement with employability. There are some limitations to the literature, attention to which might help enhance our understanding of the motivational processes underpinning employability. As can be seen from the review in this chapter, much of the published research is based upon correlational survey designs. This limits the kind of causal claims that can be supported (de Lange et al., 2003). There have been some longitudinal studies, but more would be a helpful addition to the literature. It would also be useful for researchers to publish evaluations of interventions, for example using randomised controlled trials to provide greater confidence in causal claims. There is a rich tradition of experimental research in the goal setting literature (Locke \& Latham, 2013) which could be applied to the challenge of student employability.

One possible intervention is to provide students with training (Kamau \& Spong, 2015), which could involve training in the setting of high goals (Clements \& Kamau, 2017). The impact of self-efficacy on various stages of career planning (exploration, decision-making, and job search) is one of the most consistently supported findings in the literature. There is some evidence that career management training can help enhance such self-efficacy (Jackson \& Wilton, 2016) and reduce negative thoughts about career (Belser, Prescod, Daire, Dagley, \& Young, 2018). As noted earlier, feedback is an important contributor to self-efficacy (Bandura, 1977; Ireland \& Lent, 2018), as well as leading to the setting of more challenging goals (Donovan, 2009). However, we might also consider what kind of goals should be set. So far the employability literature does not seem to have address this question. However, the broader goal-setting literature suggests that when goals are new and complex, a specific challenging performance goal may be detrimental to achievement compared to a learning goal (Locke \& Latham, 2004). In other words, when acquiring a new skill, concern over end results is less helpful than learning more about how to perform the skill. Given that many HE students will be new to career self-management, we should direct their attention initially to learning how to evaluate self, how to search for career options and so on. Providing feedback on specific skill attainment should enhance confidence, encouraging career exploration and career decision-making. Encouraging students to see struggle as normal and to see failure as a learning opportunity should aid them in remaining engaged during a process that can be discouraging (Hu et al., 2017).

As students gain competence in career self-management, they can be encouraged to set more concrete goals, e.g. for meeting a specified number of recruiters to discuss employment opportunities. Meta-analysis suggests that job search interventions that address both job skills (e.g. search, self-presentation) and motivation (e.g. goal-setting) are more effective than those interventions that address only one of these factors (Liu, Huang, \& Wang, 2014). Other interventions might include mentoring. Career mentoring has been associated with increased career planning and job search intentions, and reductions in negative job search behaviours such as procrastination, failing to network, and impulsively accepting the first job offer that is received (Renn, Steinbauer, Taylor, \& Detwiler, 2014). Further, the provision of mentoring may help supply students and graduates with relevant feedback for skill acquisition.

Although research has shown links between some stages of the career planning process, e.g. career exploration's association with decision-making self-efficacy, it would be useful to 
examine the career planning process from career exploration to job search. As was noted above, there has been a lack of research exploring job search strategies in student and graduate samples. It seems reasonable to expect that students who have appropriately engaged in career exploration, as a result of increased career decision-making self-efficacy, would be more likely to engage in a focused job search strategy. Given the criterion-based nature of a focused job search strategy, we might also expect those adopting this strategy to be more inclined to set high goals, i.e. goals that are challenging, specific, and achievable (Locke \& Latham, 1990), which should result in greater motivation and thus job search intensity, which has been shown to influence the number of job offers received. By contrast, inadequate engagement in career exploration, e.g. in terms of the time spent on this process or low effort, might be associated with later adoption of a haphazard job search strategy.

As well as further exploring motivational processes in employability for students and graduates as a larger group, it will also be helpful to examine variations in the journey from exploration to job attainment. For example, SCCT points to the role of perceived barriers in shaping career choices (Brown \& Lent, 1996). Research has demonstrated the existence of barriers for marginalised groups such as women and people of ethnic minority background in part due to consciousness of negative stereotypes (Owuamalam \& Zagefka, 2014). Further, the lack of transparency in job selection processes may contribute to perceptions that discrimination plays a role in hiring decisions (Clements, 2018). More attention is needed to addressing these barriers, including identifying the most appropriate interventions. As noted early in this chapter, motivation based interventions may address behaviour in individuals, but these are not able to address environmental challenges. There is therefore also a need for examining structural inequality in the environment, which may contribute to self-efficacy via feedback processes. In examining motivation in disadvantaged students and graduates, I therefore suggest it is important to also examine the behaviour of employers who make hiring decisions - an important source of feedback.

\section{Conclusions}

While it is not the goal of this chapter to claim that motivating students is a "magic bullet" that will address the employability agenda in full, I do argue that motivation theory and research offers insights into ways to make progress. The strongest findings in the literature identify the role of self-efficacy, which should direct our attention towards interventions that enable students to experience mastery of challenging tasks. We need to consider too the role of failure, given that this is a potential outcome of challenging activities, and in the case of job search likely to be frequent. Some research on learning goals and growth mindset suggest that these are qualities we should encourage, for example by identifying failure as a normal part of career pursuit. In order to encourage engagement with employability, we therefore should consider how students may be given opportunities for mastering career management skills and gaining feedback, e.g. via training or mentorship. We should also consider the psychological role that perceived barriers play in helping to perpetuate disadvantage for particular groups of students. Motivation theory and research often directs our attention to internal processes, but we should consider motivation as an interaction between the individual and their environment. Further attention is therefore needed to identify productive ways of helping students overcome barriers, and challenging those with influence to address structural inequality. 


\section{References}

Bandura, A. (1977). Self-efficacy: Toward a Unifying Theory of Behavioral Change, 84(2), 191-215.

Bandura, A., \& Cervone, D. (1983). Self-evaluation and self-efficacy mechanisms governing the motivational effects of goal systems. Journal of Personality and Social Psychology, 45(5), 1017-1028.

Bandura, A., \& Locke, E. A. (2003). Negative self-efficacy and goal effects revisited. Journal of Applied Psychology, 88(1), 87-99. https://doi.org/10.1037/0021-9010.88.1.87

Battisti, F. De, Gilardi, S., Guglielmetti, C., \& Siletti, E. (2016). Perceived employability and reemployment : Do job search strategies and psychological distress. https://doi.org/10.1111/joop.12156

Belser, C. T., Prescod, D. J., Daire, A. P., Dagley, M. A., \& Young, C. Y. (2018). The Influence of Career Planning on Career Thoughts in STEM-Interested Undergraduates. Career Development Quarterly, 66(2), 176-181. https://doi.org/10.1002/cdq.12131

Betz, N. E., \& Voyten, K. K. (1997). Efficacy and outcome expectations influence career exploration and decidedness. The Career Development Quarterly, 46, 179-189.

Bonaccio, S., Gauvin, N., \& Reeve, C. L. (2014). The Experience of Emotions During the Job Search and Choice Process Among Novice Job Seekers, 41(3), 237-257. https://doi.org/10.1177/0894845313486354

Brown, P., \& Hesketh, A. (2004). The mismanagement of talent. Oxford: Oxford University Press.

Brown, S. D., \& Lent, R. W. (1996). A Social Cognitive Framework for Career Choice Counselling. Career Development Quarterly, 44(June), 354-366. https://doi.org/10.1002/j.2161-0045.1996.tb00451.x

Brown, S. D., Lent, R. W., Telander, K., \& Tramayne, S. (2011). Social cognitive career theory, conscientiousness, and work performance: A meta-analytic path analysis. Journal of Vocational Behavior, 79(1), 81-90. https://doi.org/10.1016/j.jvb.2010.11.009

Browne, J. (2010). Securing a Sustainable future for higher education. October, 12(October), 64. https://doi.org/10.1787/220180871707

CBI. (2015). Inspiring Growth: CBI/Pearson Education and Skills Survey 2015, 68.

Cheung, R., \& Arnold, J. (2010). Antecedents of career exploration among Hong Kong Chinese university students: Testing contextual and developmental variables. Journal of Vocational Behavior, 76(1), 25-36. https://doi.org/10.1016/j.jvb.2009.05.006

CIPD. (2018). Labour Market Outlook. Spring 2018, 23. Retrieved from https://www.cipd.co.uk/Images/labour-market-outlook_2018-spring-1_tcm18-42044.pdf

Clarke, M. (2013). The organizational career: Not dead but in need of redifinition. The International Journal of Human Resource Management, 24(4), 684-703.

Clarke, M. (2017). Rethinking graduate employability: the role of capital, individual attributes and context. Studies in Higher Education, 0(0), 1-15. https://doi.org/10.1080/03075079.2017.1294152

Clements, A. J. (2018). Exploring diversity and employability within Higher Education students and graduates. In Division of Occupational Psychology Annual Conference abstracts (pp. 59-61). Stratford-upon-Avon. 
Clements, A. J., \& Kamau, C. (2017). Understanding students' motivation towards proactive career behaviours through goal-setting theory and the job demands-resources model. Studies in Higher Education. https://doi.org/10.1080/03075079.2017.1326022

Creed, P. A., Hood, M., \& Hu, S. (2017). Personal orientation as an antecedent to career stress and employability confidence: The intervening roles of career goal-performance discrepancy and career goal importance. Journal of Vocational Behavior, 99, 79-92. https://doi.org/10.1016/j.jvb.2016.12.007

Creed, P. A., Wamelink, T., \& Hu, S. (2015). Antecedents and consequences to perceived career goal-progress discrepancies. Journal of Vocational Behavior, 87, 43-53. https://doi.org/10.1016/j.jvb.2014.12.001

Crossley, C. D., \& Highhouse, S. (2005). Relation of Job Search and Choice Process with Subsequent Satisfaction with subsequent satisfaction. Journal of Economic Psychology, 26, 255-268. https://doi.org/10.1016/j.joep.2004.04.001

da Motta Veiga, S. P., \& Gabriel, A. S. (2016). The Role of Self-Determined Motivation in Job Search: A Dynamic Approach. Journal of Applied Psychology, 101(3), 350-361.

de Lange, A. H., Taris, T. W., Kompier, M. A. J., Houtman, I. L. D., \& Bongers, P. M. (2003). "The Very Best of the Millennium": Longitudinal Research and the Demand-Control(Support) Model. Journal of Occupational Health Psychology, 8(4), 282-305. https://doi.org/10.1037/1076-8998.8.4.282

Donovan, J. J. (2009). Antecedents of discrepancy production in an achievement setting. Journal of Managerial Issues, 21(3), 402-420. Retrieved from http://search.ebscohost.com/login.aspx?direct=true\&db=psyh\&AN=2009-18728006\&site=ehost-live

Esters, L. T., \& Retallick, M. S. (2013). Effect of an Experiential and Work-Based Learning Program on Vocational Identity, Career Decision Self-Efficacy, and Career Maturity. Career and Technical Education Research, 38(1), 69-83. https://doi.org/10.5328/cter38.1.69

Garcia, P. R. J. M., Restubog, S. L. D., Bordia, P., Bordia, S., \& Roxas, R. E. O. (2015). Career optimism: THE roles of contextual support and career decision-making selfefficacy. Journal of Vocational Behavior, 88, 10-18. https://doi.org/10.1016/j.jvb.2015.02.004

Greenbank, P. (2011). "I'd rather talk to someone i know than somebody who knows" - the role of networks in undergraduate career decision-making. Research in PostCompulsory Education, 16(1), 31-45. https://doi.org/10.1080/13596748.2011.549726

Greenbank, P. (2017). Encouraging students to develop their employability: "Locally rational" but morally questionable? In M. Tomlinson \& L. Holmes (Eds.), Graduate employability in context: Theory, research and debate (pp. 273-293). London: Palgrave Macmillan.

Guan, Y., Deng, H., Sun, J., Wang, Y., Cai, Z., Ye, L., ... Li, Y. (2013). Career adaptability, job search self-efficacy and outcomes: A three-wave investigation among Chinese university graduates. Journal of Vocational Behavior, 83(3), 561-570. https://doi.org/10.1016/j.jvb.2013.09.003

Guan, Y., Zhuang, M., Cai, Z., Ding, Y., Wang, Y., Huang, Z., \& Lai, X. (2017). Modeling dynamics in career construction: Reciprocal relationship between future work self and career exploration. Journal of Vocational Behavior, 101(February), 21-31. https://doi.org/10.1016/j.jvb.2017.04.003

Helyer, R., \& Lee, D. (2014). The Role of Work Experience in the Future Employability of 
Higher Education Graduates. Higher Education Quarterly, 68(3), 348-372.

https://doi.org/10.1111/hequ.12055

Hollenbeck, J. R., Williams, C. R., \& Klein, H. J. (1989). An Empirical Examination of the Antecedents of Commitment to Difficult Goals. Journal of Applied Psychology, 74(1), 18-23.

Hu, S., Hood, M., \& Creed, P. A. (2017). Negative career feedback and career goal disengagement in young adults: The moderating role of mind-set about work. Journal of Vocational Behavior, 102(July), 63-71. https://doi.org/10.1016/j.jvb.2017.07.006

Humburg, M., de Grip, A., \& van der Velden, R. (2017). Which skills protect graduates against a slack labour market? International Labour Review, 156(1), 25-43. https://doi.org/10.1111/j.1564-913X.2015.00046.x

Hunter, C. P. (2013). Shifting themes in OECD country reviews of higher education. Higher Education, 66(6), 707-723. https://doi.org/10.1007/s10734-013-9630-z

Ireland, G. W., \& Lent, R. W. (2018). Career exploration and decision-making learning experiences: A test of the career self-management model. Journal of Vocational Behavior, 106(November 2017), 37-47. https://doi.org/10.1016/j.jvb.2017.11.004

Jackson, D. (2015). Employability skill development in work integrated learning: Barriers and best practice. Studies in Higher Education, 40(2), 350-367.

Jackson, D., \& Wilton, N. (2016). Developing career management competencies among undergraduates and the role of work-integrated learning. Teaching in Higher Education, 21(3), 266-286. https://doi.org/10.1080/13562517.2015.1136281

Jaensch, V. K., Hirschi, A., \& Freund, P. A. (2015). Persistent career indecision over time: Links with personality, barriers, self-efficacy, and life satisfaction. Journal of Vocational Behavior, 91, 122-133. https://doi.org/10.1016/j.jvb.2015.09.010

Jiang, Z. (2016). Emotional Intelligence and Career Decision-Making Self-Efficacy: Mediating Roles of Goal Commitment and Professional Commitment. Journal of Employment Counseling, 53(1), 30-47. https://doi.org/10.1002/joec.12026

Kamau, C., \& Spong, A. (2015). A student teamwork induction protocol. Studies in Higher Education, 40(7), 1273-1290. https://doi.org/10.1080/03075079.2013.879468

Klein, H. J., Wesson, M. J., Hollenbeck, J. R., \& Alge, B. J. (1999). Goal commitment and the goal-setting process: Conceptual clarification and empirical synthesis. Journal of Applied Psychology, 84(6), 885-896.

Knight, P., \& Yorke, M. (2004). Learning, curriculum and employability in Higher Education. Oxon: Routledge.

Koen, J., Klehe, U., Vianen, A. E. M. Van, Zikic, J., \& Nauta, A. (2010). Job-search strategies and reemployment quality The impact of career adaptability. YJVBE, 77(1), 126-139. https://doi.org/10.1016/j.jvb.2010.02.004

Latham, G. P., \& Locke, E. A. (2007). New developments in and directions for goal-setting research. European Psychologist, 12(4), 290-300. https://doi.org/10.1027/10169040.12.4.290

Lent, R. W., \& Brown, S. D. (1996). Social Cognitive Approach to Career Development: An Overview. Career Development Quarterly, 44, 310-321.

Lent, R. W., \& Brown, S. D. (2013). Social cognitive model of career self-management: Toward a unifying view of adaptive career behavior across the life span. Journal of Counseling Psychology, 60(4), 557-568. https://doi.org/10.1037/a0033446 
Lent, R. W., Brown, S. D., \& Hackett, G. (1994). Toward a Unifying Social Cognitive Theory of Career and Academic Interest, Choice, and Performance. Journal of Vocational Behavior, 45(1), 79-122. https://doi.org/10.1006/jvbe.1994.1027

Lent, R. W., Ezeofor, I., Morrison, M. A., Penn, L. T., \& Ireland, G. W. (2016). Applying the social cognitive model of career self-management to career exploration and decisionmaking. Journal of Vocational Behavior, 93, 47-57. https://doi.org/10.1016/j.jvb.2015.12.007

Lent, R. W., Morris, T. R., Penn, L. T., Ireland, G. W., Lent, R. W., Morris, T. R., ... Ireland, G. W. (2018). Social - Cognitive Predictors of Career Exploration and Management Model Social - Cognitive Predictors of Career Exploration and Decision-Making : Longitudinal Test of the Career Self-Management Model.

Lim, R. H., Lent, R. W., \& Penn, L. T. (2016). Prediction of Job Search Intentions and Behaviors: Testing the Social Cognitive Model of Career Self-Management, 63(5), 594-603.

Lipshits-Braziler, Y., Gati, I., \& Tatar, M. (2015). Strategies for coping with career indecision: Concurrent and predictive validity. Journal of Vocational Behavior, 91(380), 170-179. https://doi.org/10.1016/j.jvb.2015.10.004

Liu, S., Huang, J. L., \& Wang, M. (2014). Effectiveness of Job Search Interventions : A MetaAnalytic Review, 140(4), 1009-1041. https://doi.org/10.1037/a0035923

Liu, S., \& Wang, M. (2014). Self-Regulation During Job Search: The Opposing Effects of Employment Self-Efficacy and Job Search Behavior Self-Efficacy, 99(6), 1159-1172.

Locke, E. A., \& Latham, G. P. (1990). Work Motivation and Satisfaction: Light at the End of the Tunnel. Psychological Science, 1(4), 240-246. https://doi.org/10.1111/j.14679280.1990.tb00207.x

Locke, E. A., \& Latham, G. P. (2002). Building a practically useful theory of goal setting and task motivation: A 35-year odyssey. American Psychologist, 57(9), 705-717. https://doi.org/10.1037/0003-066X.57.9.705

Locke, E. A., \& Latham, G. P. (2004). What should we do about motivation theory? Six recommendations for the twenty-first century. Academy of Management Review, 29(3), 388-403. https://doi.org/10.5465/AMR.2004.13670974

Locke, E. A., \& Latham, G. P. (2013). Goal setting theory, 1990. In E. A. Locke \& G. P. Latham (Eds.), New developments in goal setting and task performance (pp. 3-15). Hove: Routledge.

Marginson, S. (2016). High Participation Systems of Higher Education. The Journal of Higher Education, 87(2), 243-271. https://doi.org/10.1353/jhe.2016.0007

McKeown, T., \& Lindorff, M. (2011). The graduate job search process - a lesson in persistence rather than good career management? Education and Training, 53(4), 310320. https://doi.org/10.1108/00400911111138479

Owuamalam, C. K., \& Zagefka, H. (2014). On the Psychological Barriers to the Workplace: When and Why Metastereotyping Undermines Employability Beliefs of Women and Ethnic Minorities, 20(4), 521-528.

Renn, R. W., Steinbauer, R., Taylor, R., \& Detwiler, D. (2014). School-to-work transition: Mentor career support and student career planning, job search intentions, and selfdefeating job search behavior. Journal of Vocational Behavior, 85(3), 422-432. https://doi.org/10.1016/j.jvb.2014.09.004 
Rothwell, A., \& Arnold, J. (2007). Self-perceived employability: Development and validation of a scale. Personnel Review, 36(1), 23-41.

https://doi.org/10.1108/00483480710716704

Savickas, M. L. (1997). Career Adaptability: An Integrative Construct for Life-Span, LifeSpace Theory. The Career Development Quarterly. https://doi.org/10.1002/j.21610045.1997.tb00469.x

Smith, V. (2010). Review article: Enhancing employability: Human, cultural, and social capital in an era of turbulent unpredictability. Human Relations, 63(2), 279-300. https://doi.org/10.1177/0018726709353639

Sun, S., Song, Z., \& Lim, V. K. G. (2013). Dynamics of the Job Search Process : Developing and Testing a Mediated Moderation Model, 98(5), 771-784. https://doi.org/10.1037/a0033606

Super, D. E. (1975). Career Education and Career Guidance for the Life Span and for Life Roles. Journal of Career Education, 2(2), 27-43. https://doi.org/10.1177/089484537500200204

Tansley, D. P., Jome, L. M., Haase, R. F., \& Martens, M. P. (2007). The effects of message framing on college students' career decision making. Journal of Career Assessment, 15(3), 301-316. https://doi.org/10.1177/1069072707301204

Tate, K. A., Caperton, W., Kaiser, D., Pruitt, N. T., White, H., \& Hall, E. (2015). An Exploration of First-Generation College Students' Career Development Beliefs and Experiences. Journal of Career Development, 42(4), 294-310. https://doi.org/10.1177/0894845314565025

Tholen, G. (2014). Graduate employability and educational context: A comparison between Great Britain and the Netherlands. British Educational Research Journal, 40(1), 1-17. https://doi.org/10.1002/berj.3023

Tokar, D. M., Withrow, J. R., Hall, R. J., \& Moradi, B. (2003). Psychological separation, attachment security, vocational self-concept crystallization, and career indecision: A structural equation analysis. Journal of Counseling Psychology, 50(1), 3-19. https://doi.org/10.1037/0022-0167.50.1.3

Tomlinson, M. (2012). Graduate employability: A review of conceptual and empirical themes. Higher Education Policy, 25(4), 407-431. https://doi.org/10.1057/hep.2011.26

Tymon, A. (2013). The student perspective on employability.pdf. Studies in Higher Education, 38(6), 841-856. https://doi.org/10.1080/03075079.2011.604408

UK Commission for Employment and Skills. (2015). Catch 16-24. Retrieved from https://assets.publishing.service.gov.uk/government/uploads/system/uploads/attachme nt_data/file/404997/15.02.18._Youth_report_V17.pdf

Verhaest, D., \& Van Der Velden, R. (2013). Cross-country differences in graduate overeducation. European Sociological Review, 29(3), 642-653. https://doi.org/10.1093/esr/jcs044

Vertsberger, D., \& Gati, I. (2015). The effectiveness of sources of support in career decisionmaking: A two-year follow-up. Journal of Vocational Behavior, 89, 151-161. https://doi.org/10.1016/j.jvb.2015.06.004

Warner, L. M., Stadler, G., Janina, L., Knoll, N., Ochsner, S., Hornung, R., \& Scholz, U. (2018). Day-to-day mastery and self-efficacy changes during a smoking quit attempt: Two studies, 371-386. https://doi.org/10.1111/bjhp.12293 
Zhang, H., \& Huang, H. (2018). Decision-Making Self-Efficacy Mediates the Peer SupportCareer Exploration Relationship. Social Behavior and Personality, 46(3), 485-498.

https://doi.org/10.2224/sbp.6410 